\title{
Nonsteroidal sulfamate derivatives as new therapeutic approaches for Neurofibromatosis 2 (NF2)
}

Yu-chi Shen ${ }^{1,3}$, Caroline Arellano-Garcia ${ }^{1,4,5+}$, Rosa E. Menjivar ${ }^{1,4,6 \dagger}$, Ethan M. Jewett ${ }^{7}$, Wolfgang Dohle ${ }^{8}$, Sofiia Karchugina ${ }^{9}$, Jonathan Chernoff ${ }^{9}$, Barry V. L. Potter ${ }^{8}$ and Kate F. Barald ${ }^{1,2,4,6^{*}}$ (D)

\begin{abstract}
Background: Neurofibromatosis 1 and 2, although involving two different tumour suppressor genes (neurofibromin and merlin, respectively), are both cancer predisposition syndromes that disproportionately affect cells of neural crest origin. New therapeutic approaches for both NF1 and NF2 are badly needed. In promising previous work we demonstrated that two non-steroidal analogues of 2-methoxy-oestradiol (2ME2), STX3451(2-(3-bromo-4,5-dimethoxybenzyl)-7-methoxy-6sulfamoyloxy-1,2,3,4-tetrahydroisoquinoline), and STX2895 (7-Ethyl-6-sulfamoyloxy-2-(3,4,5-trimethoxybenzyl)-1,2,3,4tetrahydroisoquinoline) reduced tumour cell growth and induced apoptosis in malignant and benign human Neurofibromatosis 1 (NF1) tumour cells. In earlier NF1 mechanism of action studies we found that in addition to their effects on non-classical hormone-sensitive pathways, STX agents acted on the actin- and myosin-cytoskeleton, as well as PI3Kinase and MTOR signaling pathways. Tumour growth in NF2 cells is affected by different inhibitors from those affecting NF1 growth pathways: specifically, NF2 cells are affected by merlin-downstream pathway inhibitors. Because Merlin, the affected tumour suppressor gene in NF2, is also known to be involved in stabilizing membrane-cytoskeletal complexes, as well as in cell proliferation, and apoptosis, we looked for potentially common mechanisms of action in the agents' effects on NF1 and NF2. We set out to determine whether STX agents could therefore also provide a prospective avenue for treatment of NF2.
\end{abstract}

Methods: STX3451 and STX2895 were tested in dose-dependent studies for their effects on growth parameters of malignant and benign NF2 human tumour cell lines in vitro. The mechanisms of action of STX3451 and STX2895 were also analysed.

Results: Although neither of the agents tested affected cell growth or apoptosis in the NF2 tumour cell lines tested through the same mechanisms by which they affect these parameters in NF1 tumour cell lines, both agents disrupted actin- and myosin-based cytoskeletal structures in NF2 cell lines, with subsequent effects on growth and cell death.

Conclusions: Both STX3451 and STX2895 provide new approaches for inducing cell death and lowering tumour burden in NF2 as well as in NF1, which both have limited treatment options.

Keywords: Neurofibromatosis 2, Nonsteroidal sulfamate derivatives, Tumour treatment, Cytoskeleton

\footnotetext{
* Correspondence: kfbarald@umich.edu

${ }^{\dagger}$ Caroline Arellano-Garcia and Rosa E. Menjivar contributed equally to this work.

'Department of Cell and Developmental Biology, 3029 BSRB, University of Michigan Medical School, Ann Arbor, Michigan 48109-2200, USA

${ }^{2}$ Department of Biomedical Engineering, College of Engineering, University of Michigan, Ann Arbor, Michigan 48109-2099, USA

Full list of author information is available at the end of the article
}

(c) The Author(s). 2019 Open Access This article is distributed under the terms of the Creative Commons Attribution 4.0 International License (http://creativecommons.org/licenses/by/4.0/), which permits unrestricted use, distribution, and reproduction in any medium, provided you give appropriate credit to the original author(s) and the source, provide a link to the Creative Commons license, and indicate if changes were made. The Creative Commons Public Domain Dedication waiver (http://creativecommons.org/publicdomain/zero/1.0/) applies to the data made available in this article, unless otherwise stated. 


\section{Background}

Both Neurofibromatosis 1 and 2 (NF1 and NF2) are disorders characterized by the formation of tumours of the peripheral and central nervous system [1], primarily affecting cells of neural crest origin [2]. Although other organ systems and cell types are affected in both NF1 and NF2, the cell of origin in most malignancies is the Schwann cell [1]. Both NF disorders arise through autosomal dominant inheritance with loss-of-function mutations in the tumour suppressing functions of the respective tumour suppressor genes: Neurofibromin (NF1) and Merlin (NF2) [3, 4].

Neurofibromatosis type II (NF2) is associated with loss-of-function mutations in the NF2 gene that encodes the multi-functional protein, Merlin (Moesin-EzrinRadixin-like protein) [5], also known as Schwannomin. Merlin is currently an out-group member of the ERM (Ezrin-Radixin-Moesin) protein family because it is the only one in the family to function as a tumour suppressor. Strong evidence suggests that Merlin regulates the assembly of apico-lateral junctional complex [6]. Merlin is also involved in stabilizing membrane-cytoskeletal complexes [7], in cell proliferation [8-10], and in apoptosis [10]. Conditional knockouts of Merlin result in the formation of meningiomas [11]. Conditional deletion of Merlin also contributes to hyperplasia of Schwann cells and of neural-crest derived odontoblasts, osteoblasts, and renal tubular cells. It also results in metastases of osteoscarcoma and fibrosarcoma [12]. Loss of Merlin activates several mitogenic pathways including Rac1/Pak $[13,14]$, Ras/Raf, PI3K/AKT, mTORC1 and Wnt/ $\beta$-catenin pathways $[15,16]$. Merlin also mediates the Hippo pathway and inhibits proliferation, acting in the nucleus to bind E3 ubiquitin ligase CRL4 ${ }^{\mathrm{DCAF} 1}$ [17].

NF2 affects one in 25,000-30,000 live births worldwide. A hallmark of the disease is the formation of bilateral vestibular Schwannomas, as well as the formation of multiple meningiomas, extramedullary spinal tumours, and ependymomas [18]. Uncontrolled growth of these tumours can also lead to cataracts, hearing loss, balance issues and paralysis $[5,6,19]$. Although malignant transformations of NF2 tumours are rare, better therapeutics are needed, because numerous tumours can lead to early morbidity and early mortality (age 36) [5].

Current treatment options for NF2 tumours include surgical resection of either part of or the complete tumour, which is difficult to perform without damaging nerves. Stereotactic radiosurgery is also an option, however the risk of malignant transformation rises several years post-surgery [20,21]. Alternate treatment options for NF2 tumours include inhibitors of the epidermal growth factor receptor (EGFR) [22], inhibitors of the vascular endothelial growth factor (VEG-F) [23-25], inhibitors of mTORC1 [26], an inhibitor of platelet- derived growth factor (PDGF) [27], and an inhibitor of histone deacetylase (HDAC) [28]. However, such treatments have resulted in mixed and sometimes limited success in human trials [29]. Current phase II clinical trials explore better treatment options through inhibition of the mTORC1, PDGF-R, VEGF and anti-angiogenic pathways (NCT01419639; $\quad$ NCT00561665; NCT00589784; NCT02104323). To date, no phase III clinical trials for the treatment of NF2-related disorders have been initiated.

Previous studies from our laboratories [30] demonstrated that sulfamate ester derivatives of a class of nonsteroidal tetrahydroisoquinoline (THIQ)-derived agents, derived by SAR translation from the naturally occurring anticancer metabolite of 17- $\beta$ estradiol, known as 2methoxyoestradiol (2ME2) [31, 32] are highly effective at reducing cell viability in hormone-responsive NF1 cell lines. These derivatives, known as STX3451 and STX2895, are capable of inducing apoptosis in cell lines derived from two malignant peripheral nerve sheath tumours (MPNST) at very low concentration [30].

The two non-steroidal 2ME2 analogues, STX3451 (2(3-bromo-4,5-dimethoxybenzyl)-7-methoxy-6-sulfamoyloxy-1,2,3,4-tetrahydroisoquinoline) and STX2895 (7Ethyl-6-sulfamoyloxy-2-(3,4,5-trimethoxybenzyl)-1,2,3,4tetrahydroisoquinoline) (Fig. 1) were synthesized as previously described for treatment of a variety of hormoneresponsive cancers, including breast cancer and prostate cancer [31-35]. STX3451 displays high anti-proliferative activity across the NCI 60 cell line panel (average GI50 $40 \mathrm{nM}$ ) [31]. STX2895 also has a high anti-proliferative activity with $\mathrm{GI}_{50}$ of 40 and $52 \mathrm{nM}$ on DU-145 human prostate and MDA MB-231 breast cancer cell lines, respectively [32]. The ability of STX3451and STX2895 to disrupt normal microtubule dynamics through competitive binding to the colchicine site, in a cell-free system, appears to make a significant contribution to their antiproliferative effects [31, 32]. Sulfamoylated derivatives of 2ME2, particularly its bis-sulfamate 2ME2BisMATE, have been shown to be more effective, more bioavailable, resistant to catabolism in the gut and liver than $2 \mathrm{ME} 2$ itself [36], and also interact with carbonic anhydrase IX, a hypoxic tumour target [37]. Although the bioavailability of STX3451 and STX2895 has not been examined in an animal model, the in-vitro effects of these molecules on NF1 cell lines derived from both benign and malignant human tumours are particularly promising [30]. These agents are multi-faceted with multiple modes of action, including those that are hormoneindependent ([30]). Recently, some of us also demonstrated that THIQ derivatives, including STX2895 and STX3451 exert anti-proliferative and antimitotic effects, induce apoptosis and involve autophagic processes in MDA-MB-231 metastatic breast and A549 epithelial lung carcinoma cell lines [38]. 
<smiles>COc1cc2c(cc1O)CC[C@@H]1[C@@H]2CC[C@]2(C)[C@@H](O)CC[C@@H]12</smiles><smiles>CCc1cc2c(cc1OS(N)(=O)=O)CCN(Cc1cc(OC)c(OC)c(OC)c1)C2</smiles>

STX2895

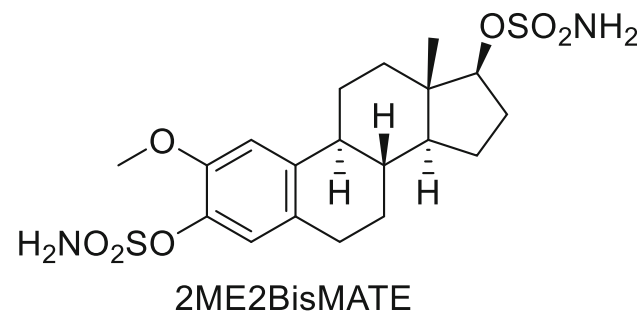<smiles>COc1cc2c(cc1OC(C)(C)C)CN(Cc1cc(Br)c(OC)c(OC)c1)CC2</smiles>

Fig. 1 Chemical structures of 2-MeE2, 2ME2BisMATE, STX2895 and STX3451

Here, we show that NF2 status plays a role in the effectiveness of these non-steroidal 2ME2 derivatives on cell viability in vitro. STX2895 and STX3451 treatment on NF2 null (-/-) cell lines induces nuclear fragmentation, microtubular disruption, inhibition of cellular migration/wound healing, and can induce apoptosis in both benign and malignant NF2 tumour-derived cells.

\section{Methods}

\section{Cell culture}

NF2-null malignant meningioma KT21-MG1-Luc5D cells (KT21 cells, derived from a human malignant meningioma cell line KT21-MG1 [39]) and the luciferaseexpressing NF2-deficient benign meningioma cell line, Ben-Men-1-LucB (Ben-Men-1 cells, derived from a human benign meningioma cell line Ben-Men-1 [40]), have been described previously [41]. CH157MN cells (a human malignant meningioma NF2 ${ }^{-/-}$cell line from a 41year-old woman [42]) were generously provided by Dr. Yancey Gillespie at the University of Alabama Birmingham. HEI-193 cells (a benign vestibular Schwannoma cell line from a 56-year-old Neurofibromatosis type 2 (NF2) patient [43]) were kindly provided by Dr. Xandra Breakefield, Massachusetts General Hospital. The IOMM-Lee (a malignant Meningioma $\mathrm{NF}^{+/+}$cell line derived from the brain of 61-year-old man [44]) was obtained from Dr. Randy Jensen at the University of Utah. BJ (ATCC ${ }^{\circ}$ CRL-2522 $^{\mathrm{m}}$, human foreskin fibroblast) cells were a gift from Dr. Sem Hin Phan, University of Michigan. Most cell lines were cultured in high-glucose Dulbecco's Modified Eagle Medium (DMEM) (Gibco), supplemented with $10 \%$ fetal bovine serum (FBS)
(Atlanta Biologicals, Flowery Branch, GA), 2 mM L-glutamine and $100 \mathrm{U} / \mathrm{ml}$ penicillin/streptomycin (Gibco), at $37^{\circ} \mathrm{C}$ in a humidified $5 \% \mathrm{CO}_{2}$ incubator [41]. HEI-193 cells were maintained in DMEM/10\% FBS with forskolin (Cayman Chemical, Ann Arbor, MI), recombinant glial growth factor 2 (R\&D Systems, Minneapolis, MN), and geneticin (Gibco). CH157MN cells were grown in MEM/F12 medium with 7\% FBS.

\section{Compounds}

STX3451 and STX2895 were synthesized according to previously published protocols [31, 45]. Pak inhibitors, Frax1036 and PF3758309 were used as control to be compared with the effects of STX3451 and STX2895 on NF2-deficient cells. Frax1036 was purchased from Afraxis Inc., San Diego, CA [39]. PF3758309 was synthesized according to published protocols [46].

\section{Cell viability assays}

Cells were plated in 96-well Primaria ${ }^{\text {ma }}$ plates (BD Falcon, $1 \times 10^{4} /$ well) determined by a hemocytometer. STX3451 or STX2895 at concentrations of $100 \mathrm{nM}, 300$ $\mathrm{nM}, 600 \mathrm{nM}$, and $1000 \mathrm{nM}$ was dissolved in vehicle (DMSO; Sigma-Aldrich, St Louis, MO, USA) and were added to the wells 2 hours after plating the cells. The final concentration of DMSO was 1\%. PF3758309 (PF) and Frax1036 concentrations ranged from $0.03 \mu \mathrm{M}$ to $20 \mu \mathrm{M}$ and from $2.5 \mu \mathrm{M}$ to $25 \mu \mathrm{M}$, respectively. The final concentration of DMSO was 2.5\%. STX3451, STX2895, PF, or Frax1036 was replenished after 2 days of culture. Cell growth was assessed using CellTiter 96 (Promega, Madison, WI, USA) [30, 47, 48]. 


\section{Immunohistochemistry}

40,000-80,000 cells plated on $0.1 \%$ porcine gel-coated coverslips were treated with DMSO, STX3451, STX2895, PF3758309, or Frax1036 for various time periods. Immunocytochemistry and counter-staining with DAPI (4',6-diamidino-2-phenylindole, Molecular Probes, Eugene, OR), were carried out as reported previously [45]. Microtubules were visualized using antibodies for $\alpha$-tubulin (1:500, Sigma). Apoptosis was assessed by an anti-annexin V antibody (1:500, Abcam ab14196). Fluorescent (Alexa Fluor 488 or 594) anti-rabbit or antimouse secondary antibodies (Life Technologies) were used for visualizing the labeled cells. Fluorescence micrographs were taken with an Olympus BX-51 microscope and processed with Adobe Photoshop.

\section{Wound-healing assays}

The ability of cells to migrate was assessed by woundhealing assays $[49,50] .2 \times 10^{5}$ cells were plated in a 10 $\mathrm{mm}$ cell culture dish and allowed to grow to confluence. Wounds were made using a ruler to maintain a straight edge and a $200 \mu \mathrm{l}$ pipette tip applied to the bottom of the dish to remove the cells. The culture plates were then washed twice with PBS. Fresh medium with DMSO, STX3451, or STX2895 was added to the dishes. STX3451 and STX2895 were used at $300 \mathrm{nM}$ for KT21, Ben-Men-1, and HEI-193 cells, 1000 nM for IOMM-Lee and BJ cells. Photographs of the wounds and subsequent cell migration and "wound filling" were taken using a Nikon SMZ1500 dissecting microscope and digital camera (Nikon Digital Sight) at the time points indicated. The dimensions of the "wound" were measured with ImageJ software.

\section{Western blots}

Cell lysates were collected after $24 \mathrm{~h}$ treatments with DMSO, STX3451, STX2895, PF, or Frax1036. Western blotting was performed as described in the studies on NF1 [30]. Membranes were incubated with antibodies (all from Cell Signaling Technology) to phosphorylated S6, S6, cyclin D, phosphorylated MEK, MEK, Pak 1/2, phospho-Pak1 (pPak1), phospho-Pak2 (pPak2) and GAPDH. The peroxidase-coupled secondary antibody (1: 1000) and chemiluminescent HRP substrate (Millipore) were used to detect the labeled bands. Pixel density was quantified with ImageJ (NIH) software.

\section{Results}

The effects of nonsteroidal analogues of 2ME2BisMATE on cell viability depend on NF2 status

The STX therapeutic agents tested are multifaceted in their mechanisms of action. This study was directed at discovering whether the mechanisms of action that make the STX agents promising potential therapeutics for the treatment of NF1 would also apply to the potential treatment of NF2. Our previous studies concluded that the agents' effects on the growth of and induction of apoptosis in human NF1 tumour cells were both through NF1-specific pathways and through significant effects on both the actin-based and myosin-based cytoskeleton [30]. The same approaches in the present study on NF2 led to the findings that, in NF2 human tumour cells, none of the pathways that were found to be affected in NF1 was affected in NF2. However, effects on NF2 cell growth were also mediated through the STX agents' effects on the cytoskeleton.

In our earlier report [30] we demonstrated that relatively low concentrations of STX3451 have profound effects on the cell viability of NF1 tumour cell lines, even in the presence of elevated oestrogen and progesterone hormones. We also demonstrated that these effects were caused by more than one mechanism of action. To examine whether STX3451 or STX2895 affected the viability of human NF2 tumour cells, in a manner similar to those in NF1 tumour cells, we exposed Ben-Men$1 \mathrm{NF}^{-/-}$benign meningioma cells), CH157MN (NF2 ${ }^{-/-}$ meningioma cells), HEI-193 (NF2 ${ }^{-1-}$ benign vestibular Schwannoma cells), KT21 (NF2 ${ }^{-/-}$malignant meningioma cells) and IOMM-Lee (NF2 ${ }^{+/+}$malignant meningioma cells) to the individual agents or to a combination of the two. Our results showed that both agents either completely blocked cell proliferation or induced cell death in $\mathrm{NF}^{-/-}$cells whether the cell lines were derived from benign or malignant tumours (Fig. 2). Cell proliferation of wild-type NF2 malignant meningioma IOMMLee cells was notably reduced when treated with either drug. In all but the CH157MN cell line, STX2895 was slightly more potent than STX3451. BJ fibroblast cells were seen to have reduced cell growth rate when treated with either compound, but cell viability was not reduced even with the highest concentrations of either drug we used $(1 \mu \mathrm{M})$.

Chow et al. had previously shown that Pak inhibitors reduced proliferation and survival of both Ben-Men-1 and KT21 cells [41]. We set out to examine the effects of such inhibitors on other NF2-null cells as well as CH157MN cells. Our results demonstrate that Frax1036 (a group I Pak-specific inhibitor) is less potent than the analogues of 2ME2BisMATE in promoting cell death of either CH157MN or HEI-193 cells (Fig. 3). STX3451 halted CH157MN cell growth completely at a concentration of $1 \mu \mathrm{M}$, whilst STX2895 induced cell death at 300 $\mathrm{nM}$. By contrast, these cell lines still grew relatively rapidly in $5 \mu \mathrm{M}$ Frax1036. Only at $15 \mu \mathrm{M}$ did Frax1036 induce apoptotic cell death in CH157MN. PF3758309 (PF), an inhibitor for both groups I and II Paks, on the other hand, was found to be more potent than STX3451 but less potent than STX2895 for CH157MN cells. PF at 

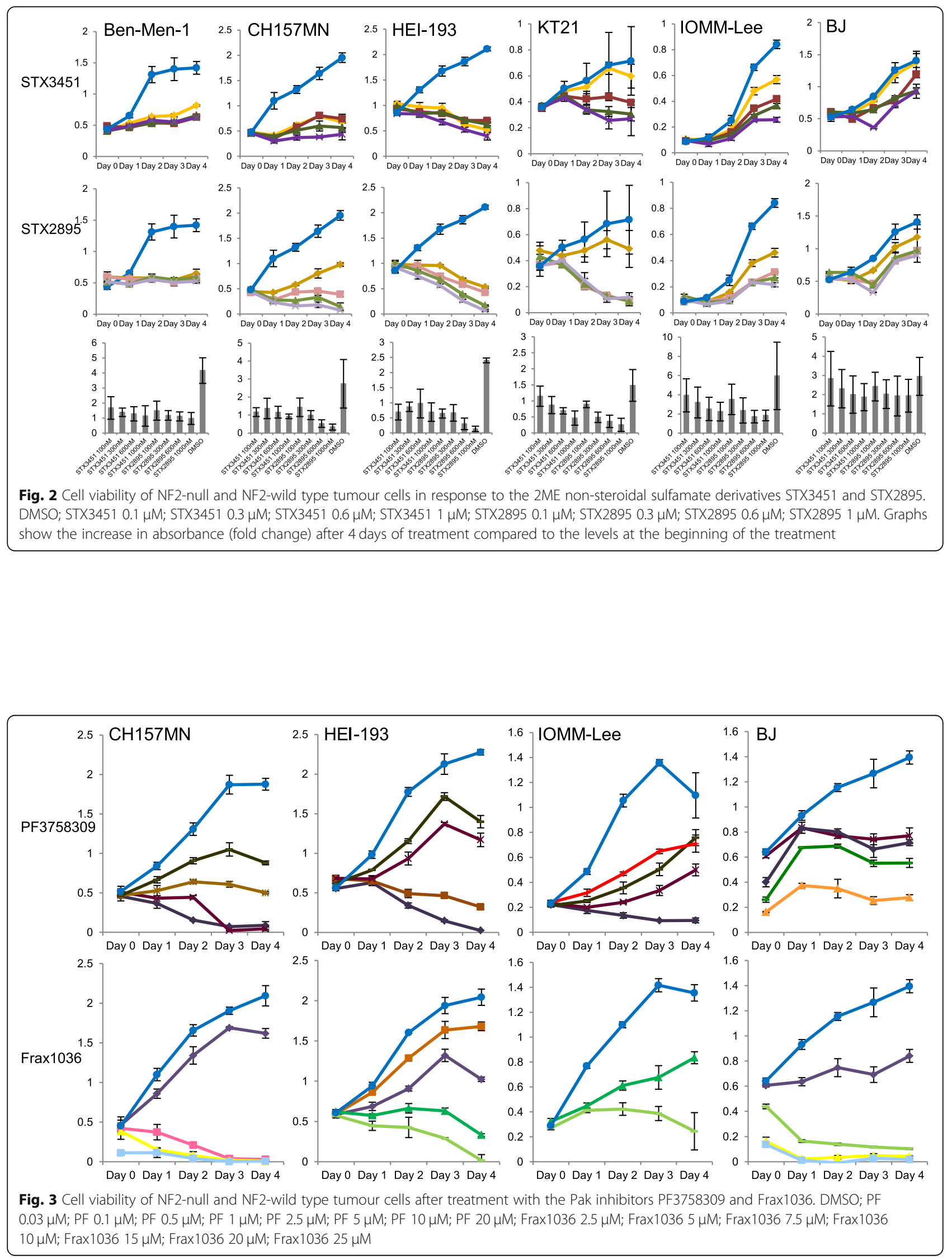
$500 \mathrm{nM}$ halted cell growth of $\mathrm{CH} 157 \mathrm{MN}$ cells (Fig. 3), whilst STX2895 and STX3451 had the same effect- halting $\mathrm{CH} 157 \mathrm{MN}$ cell growth- at $300 \mathrm{nM}$ and $1000 \mathrm{nM}$, respectively (Fig. 2). Both STX3451 and STX2895 were very effective at low concentrations $(100 \mathrm{nM})$ in promoting the death of HEI-193. However, neither PF nor Frax1036 proved to be as potent for reducing cell viability in benign vestibular Schwannoma HEI-193 cells. We did not test concentrations higher than $1 \mu \mathrm{M}$ with the non-steroidal analogues for any of the cell lines, except for IOMM-Lee cells. PF3758309 began to cause cell death in IOMM-Lee cells between 1 and $5 \mu \mathrm{M}$, whilst the cells still grew - albeit at a lower rate - even at $7.5 \mu \mathrm{M}$ Frax1036. BJ cells were less sensitive to PF and Frax1036 than any of the tumour cell lines. Even at $20 \mu \mathrm{M}$, PF did not reduce BJ cell viability, although BJ cell viability decreased at concentrations of Frax1036 between 5 and $10 \mu \mathrm{M}$. Of the 4 agents we tested, STX2895 was the most robust for inducing apoptosis in NF2 tumour cell lines. PF and STX3451 displayed about the same potency, whilst Frax1036 was the least effective in blocking cell proliferation or causing apoptosis.

Next we investigated the mode of action of STX agents on the growth and/or induction of apoptosis in NF2 tumour cells and compared the effectiveness of these agents with those of Pak inhibitors. Our results, which will be discussed in the next section, indicated that STX agents caused depolymerization of microtubules, whilst Pak inhibitors did not have this effect.

Despite carefully repeated experiments $(n=5$ [at least], on each of the cell lines) testing whether the STX agents act mechanistically on the same pathways on which we found them to be very effective on growth and apoptosis in human NF1 tumour cell lines, we currently have been able to detect NO significant effects of either of the agents on the growth, morphology of NF2 cell lines through the pathways that are known to be important for the growth of or cell death in NF1 human tumour cell lines (as detailed in Shen et al., 2015 [30]). This is an important point, because if the STX agents successfully reduce growth or induce apoptosis in NF2 cell lines as they do in NF1 cell lines, understanding the mechanism or mechanisms by which such effects occur is critical in order to plan the required preclinical animal studies that must follow the cell line studies if the agents are to be helpful eventually to both NF1 and NF2 patients.

\section{STX3451 and STX2895 cause nuclear fragmentation in NF2-null tumour cells}

Our previous studies on NF1 cell lines demonstrated that STX3451 caused nuclear fragmentation in both the NF1-null malignant tumour cell line ST88 and in benign plexiform neurofibroma (PNF) cells, although this result was less significant for PNF cells [30].

We therefore examined whether this effect was also observed in our studies of NF2-null tumour cells. DAPI staining revealed that treatment with both STX3451 and STX2895 resulted in a dramatic increase in nuclear fragmentation, which was seen in both KT21 and Ben-Men1 cell lines $48 \mathrm{~h}$ after treatment; with STX3451being more effective than STX2895 (Fig. 4). At 24h, although STX3451 increased nuclear fragmentation in KT21 cells, the effect of STX2895 at this earlier time point was not significant, implying that most of the fragmentation caused by STX2895 occurred between 24 and $48 \mathrm{~h}$ after treatment. Further, nuclei fragmentation of KT21 was observed $72 \mathrm{~h}$ after treatment, with STX2895 more effective than STX3451, suggesting that STX2895 has a slower but consistent pace in causing fragmentation of nuclei.

For Ben-Men-1 cells, the dramatic increase seen in nuclei fragmentation also fell between 24 and $48 \mathrm{~h}$ after treatment, with STX3451 slightly more effective than STX2895. Neither analog caused significant increase of fragmentation between 48 and $72 \mathrm{~h}$, presumably due to the greatly reduced cell viability seen during this time
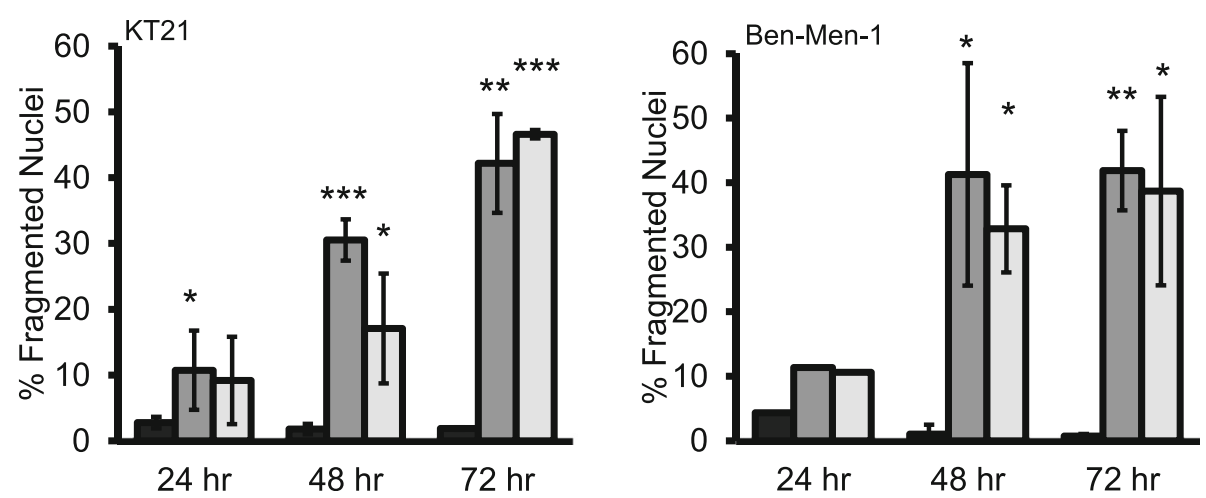

Fig. 4 STX3451 and STX2895 caused nuclear fragmentation in both KT21 and Ben-Men-1 cells. DMSO control; STX3451; STX2895. Statistical significance: ${ }^{*} p<0.05$; ${ }^{* *} p<0.01$; ${ }^{* *} p<0.005$ 
(Fig. 2). However, the nonsteroidal sulfamate derivatives of $2 \mathrm{ME} 2$ effectively promoted nuclear fragmentation in both NF1 [30] and NF2 null tumour cell lines.

\section{STX3451 and STX2895, but not the Pak inhibitors, induce microtubular disruption; treatment with all agents resulted in tumour cell apoptosis}

STX3451 induced apoptosis and disrupted both microtubule- and microfilament-based cytoskeletal structures in NF1 ST88 cells, but did not induce programmed cell death in the benign PNF tumour cells [30]. To analyze apoptosis, we used an Annexin V antibody [51] to stain cells treated with STX agents and PAK inhibitors for $72 \mathrm{~h}$. In healthy, quiescent cells phosphatidylserine (PS) is located exclusively at the inner cell membrane. Exposure of PS in a cell indicates early apoptosis [52]. Annexin V has a high binding affinity for PS in the presence of $\mathrm{Ca}^{2+}$ and is therefore commonly used to detect apoptotic cells.

For KT21 cells, treatment with both STX3451 and STX2895 at $300 \mathrm{nM}$ resulted in about $60 \%$ annexin Vpositive-cells (Fig. 5). Even at much higher concentrations $(7.5 \mu \mathrm{M}$ and $2 \mu \mathrm{M}$, respectively), PF and Frax1036 resulted in only 30 and $20 \%$ of apoptotic KT21 cells at $72 \mathrm{~h}$. Less than $10 \%$ of cells treated with the DMSO vehicle were annexin V-positive. Except for Frax1036, the increases seen in annexin V-positive cells are statistically significant.

For Ben-Men-1 cells, although cell viability was little affected after 4 days of treatment, about $40 \%$ of these cells treated with either STX3451 or STX2895 (at 600 $\mathrm{nM}$ ) were apoptotic at $72 \mathrm{~h}$, indicating that these analogues of 2ME2 also have effects on cell growth/apoptosis in the benign Ben-Men-1 cells. However, the effects seen are much less than those seen when either STX agent was used to treat malignant KT21 cells. By contrast, $72 \mathrm{~h}$ treatment with PF resulted in $20 \%$ annexin $\mathrm{V}$-positive cells at very low concentration, the IC50 for KT21 was $29.25 \mathrm{nM}$ [41]. Frax1036 at $1.9 \mu \mathrm{M}$ caused $30 \%$ of Ben-Men-1 cells to become apoptotic at $72 \mathrm{~h}$. Even though IOMM-Lee cell line viability was higher after 4days, despite treatment with STX3451 or STX2895 at $1000 \mathrm{nM}$, annexin V-staining at $72 \mathrm{~h} \mathrm{dem-}$ onstrated that 35 and $45 \%$ of these cells were undergoing cell death, respectively. The reason for this inconsistency is not clear. It could be that cells were still proliferating at earlier times, but eventually would be killed by higher concentrations of these 2ME2 analogs. Further studies are needed to determine the mechanism of action of these agents in IOMM-Lee cells. PF at $1.5 \mu \mathrm{M}$ and Frax1036 at $10 \mu \mathrm{M}$ resulted in apoptosis in about $25 \%$ of cells at $72 \mathrm{~h}$, indicating that these agents are less effective in killing IOMM-Lee cells than either STX3451 or STX2895.
Finally, STX3451 and STX2895 at $1000 \mathrm{nM}$ did not significantly increase the percentage of annexin $\mathrm{V}$ positive BJ cells at $72 \mathrm{~h}$, consistent with the results seen in the cell viability assays (discussed above). At concentrations that effectively induced apoptosis in NF2 tumour cells, STX3451 and STX2895 did not cause such programmed cell death in BJ fibroblasts. PF at $5 \mu \mathrm{M}$ also did not increase the percentage of annexin V-positive BJ cells, whilst Frax1036 at $10 \mu \mathrm{M}$ induced 55\% cells to go through apoptosis.

STX3451 has been demonstrated to depolymerize microtubules in both NF1 ST88 and PNF cell lines [30]. Our current studies also confirmed the effect of STX3451 and STX2895 on microtubules in NF2-null tumour cells. Both agents caused cells to round up and to present with much shorter microtubules in all of the cell lines examined (Fig. 5a). Failure of cytokinesis was also seen in these treated cells, where cells with larger diameters were observed (Fig. 5a). PF and Frax1036, in contrast to the STX agents, did not result in microtubule disruption in most of the cell lines tested. A high concentration of Frax1036 $(10 \mu \mathrm{M})$ resulted in rosette-like clusters of IOMM-Lee cells. However, the mechanism for this rosette formation is unknown.

Our results from annexin $\mathrm{V}$ and $\alpha$-tubulin staining (Fig. 5) suggest that the two analogs of $2 \mathrm{ME} 2$ that we evaluated act differently from the Pak inhibitors on NF2 cells, especially in the effects seen on the microtubular cytoskeleton. However, both STX agents and Pak inhibitors can promote apoptosis in NF2 tumour cells.

\section{STX3451 and STX2895 decrease cell migration}

PF and Frax1036 have been shown to inhibit invasiveness of both KT21 and Ben-Men-1 cells [41]. We, therefore, explored the possibility that STX3451 and/or STX2895 could also block cell migration in NF2-null tumour cells using "wound-healing" assays [49, 50] as we had previously done for NF1 cells [30]. We found that the cell lines, which we evaluated migrated to fill the wound gaps at different rates, and that STX3451 and STX2895 inhibited wound healing in the NF2 cells with different kinetics. The untreated control Ben-Men-1 cells were able to fill in the gaps by 4 days after the wound was made. However, cells treated with either STX3451 or STX2895 also filled in the gap, but at a much slower pace (Fig. 6). Control KT21 cells did not completely fill the gap even 4 days after the lesion was made, although the gap was almost eliminated by this time (Fig. 6a). KT21 cells treated with either STX3451 or STX2895 migrated to fill the gap at a much slower rate than the control cells and stopped migration entirely after $46 \mathrm{~h}$. Both IOMM-Lee and HEI-193 cells closed the gap in DMSO-treated cultures (the control condition) after 4days. However, STX3451 and 


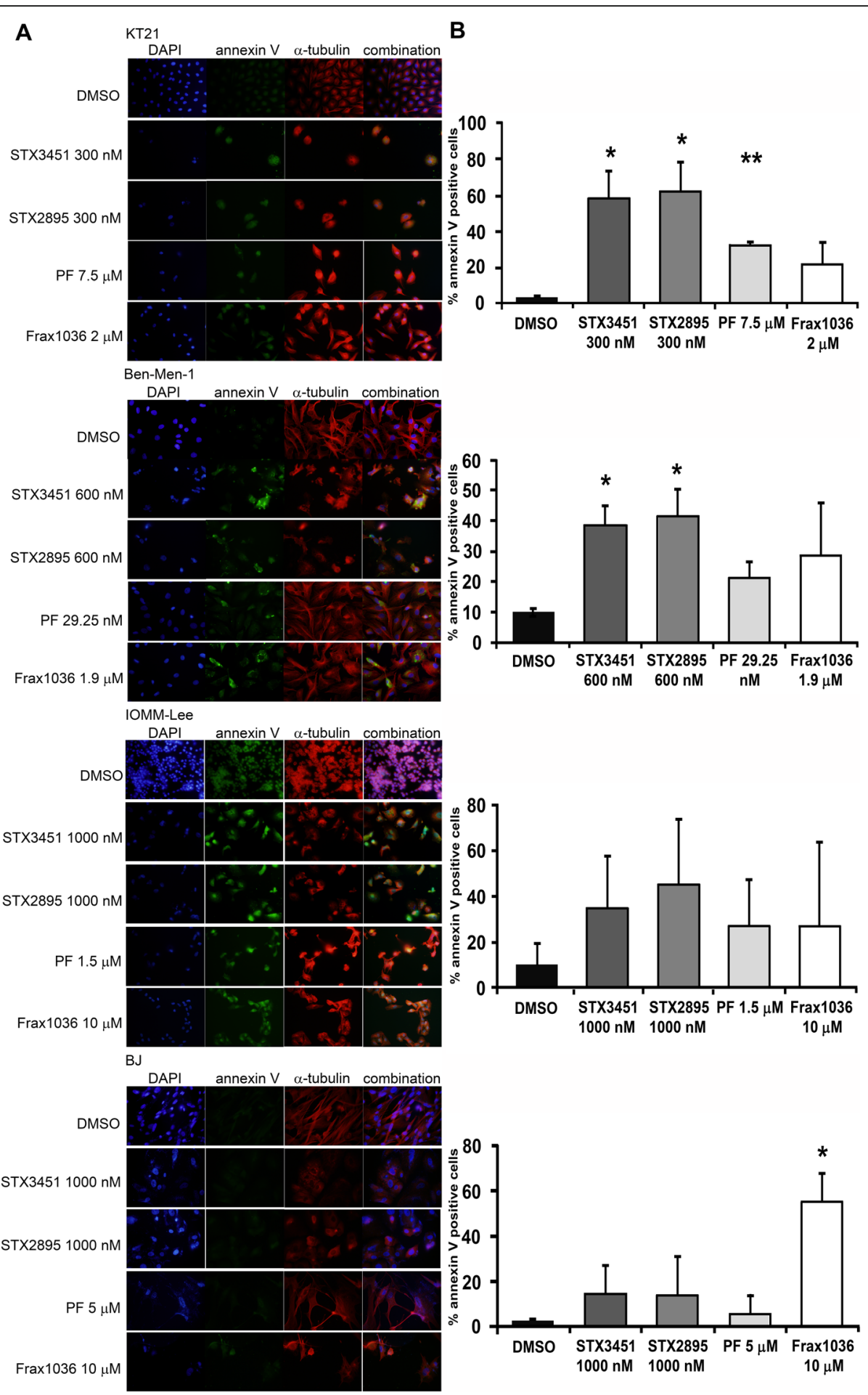

Fig. 5 a STX3451 and STX2895 resulted in cytoskeletal structural changes and apoptotic cell death in NF2 tumor cells after $72 \mathrm{~h}$ of treatment. Cells were stained with DAPI for nuclei (blue), anti-a-tubulin antibody for microtubules (red), and annexin $V$ for apoptotic cells (green). $\mathbf{b}$ Percentage of annexin-V-positive cells for control and treated conditions. DMSO; STX3451; STX2895; PF; Frax1036. Statistical significance: ${ }^{*} p<0.05 ;{ }^{* *} p<0.01$

STX2895 only slowed down the migration of these cells slightly for the first 2 days. The distance cells migrated to fill the gap by the third and fourth days was almost the same as that seen in the control cells treated with the DMSO vehicle, indicating that STX3451 and STX2895 did not inhibit cell migration over a period of 4 days, if this 

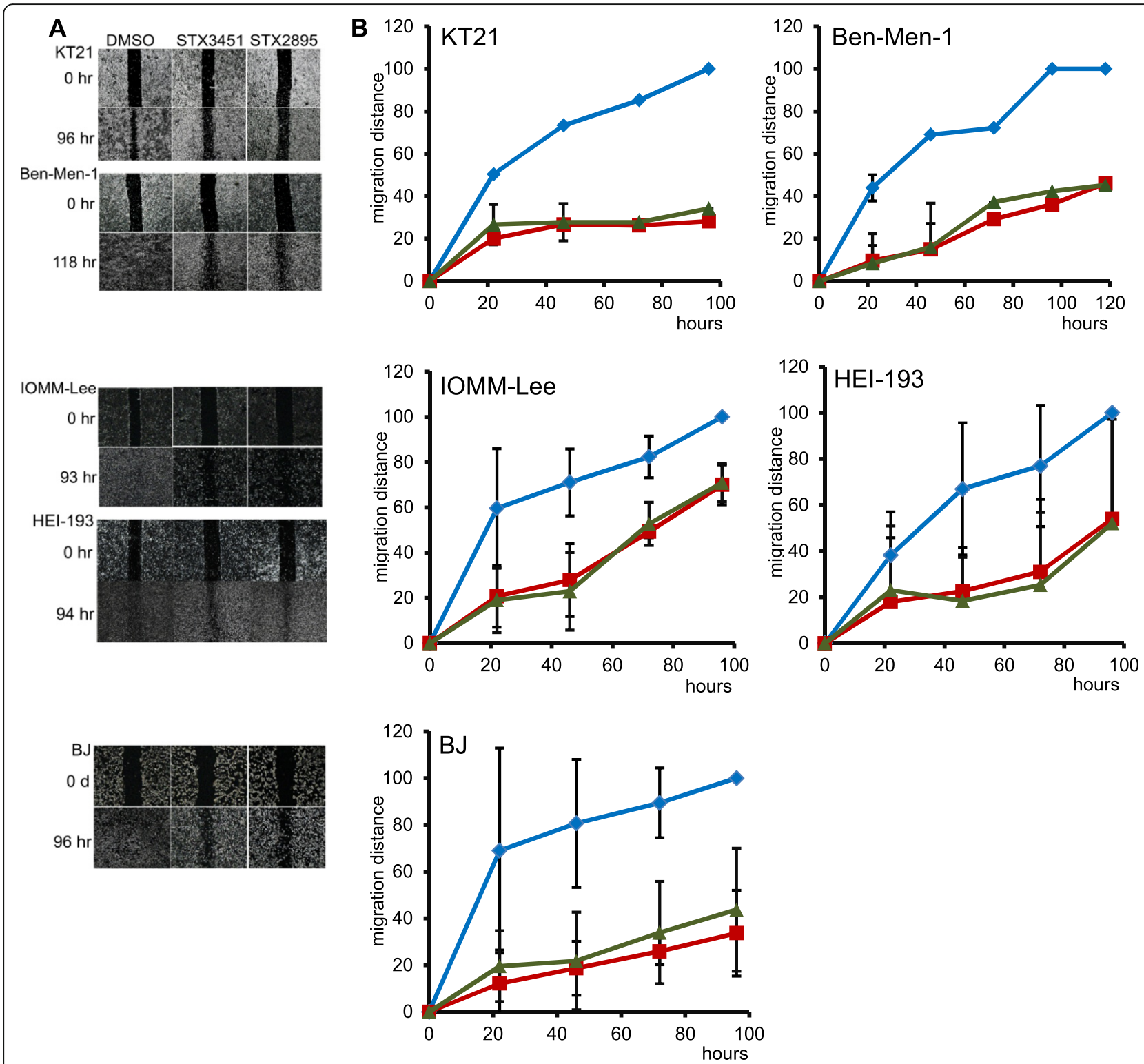

Fig. 6 STX3451 and STX2895 treatment resulted in reduced cell migration of NF2 tumour cells and BJ cells after "wounding". a Microscopic pictures of wound healing assays showing introduction of the wound $(0 \mathrm{~h})$ and at the end of the observation period (96-118 h after wound introduction). $\mathbf{b}$ Graphs show comparisons of the distances the cells moved from the wound periphery toward the middle of the open area at various time points. DMSO; STX3451; STX2895

much time was allowed for recovery. Control BJ cells healed the wound gradually over the $96 \mathrm{~h}$ period, whilst cells treated with STX3451 and STX2895 migrated more slowly, and the gap was not filled in until 4 days after injury. Our results suggest that STX3451 and STX2895 are both effective in impeding the migration of KT21, Ben-Men-1, and BJ cells, but were less effective in preventing either IOMM-Lee or HEI-193 cells from migrating.

\section{Discussion}

We previously demonstrated that STX3451 induces apoptosis in human NF1-deficient ST88 and S462 malignant peripheral nerve sheath tumour (MPNST) cell lines at very low concentration $(300 \mathrm{nM})$, whilst arresting cell proliferation in an $\mathrm{NF}^{-/}$benign plexiform neurofibroma (PNF) [30]. In this study, using approaches and analyses identical to those we previously used in our NF1 tumour cell studies [30], we found that STX3451 and another potent sulfamoylated non-steroidal compound, STX2895, effectively induced cell death in NF2 deficient cell lines in vitro at concentrations between $0.3 \mu \mathrm{M}$ and $1 \mu \mathrm{M}$. These two compounds have similar potencies in most of the NF2 cell lines, although STX2895 is slightly more potent than STX3451. 
Intriguingly, our results showed that STX3451 and STX2895 were not as effective against a permanent NF2 wild type malignant meningioma cell line, IOMM-Lee, indicating that NF2 status could be important for the effects of these compounds. Our results also showed that these 2ME2 analogs were more potent than Pak inhibitors in inducing cell death. However, their mechanistic effects on the cells were different: STX3451 and STX2895 affect microtubules (Fig. 5), whilst Pak inhibitors act through the mTORC pathway and affect cell cycle progression by reducing $\beta$-catenin signaling, followed by reducing cyclin D1 expression [39]. Further, Pak inhibitors did not affect microtubule polymerization at the concentrations we used. Therefore, the 2ME2 analogs provide a new means of treating NF2-related disorders, and could potentially be combined with Pak inhibitors in multi-drug approach treatments.

We also found that STX3451 and STX2895 caused nuclear fragmentation and apoptosis in NF2 deficient cells, as shown by annexin $\mathrm{V}$ staining. We found that by $72 \mathrm{~h}$ after treatment with STX3451, the percentage of annexin $\mathrm{V}$ positive cells amongst the attached cells was 19 times greater in KT21 and 4 times greater in Ben-Men-1 cells than in control cells. Treatment with STX2895 resulted in 20 times more annexin V positive KT21 cells and 4.5 times more Ben-Men-1 cells than that of the controls. STX3451 and STX2895 also increased the percentage of annexin $\mathrm{V}$ positive IOMM-Lee cells, but this increase was not statistically significant, indicating that NF2 wildtype tumour cells are less sensitive to the 2ME2 analogs. In addition, as was also shown in our studies of NF1deficient cells [30], STX3451 caused microtubule depolymerization in NF2-deficient cells. STX2895 had very similar effects to those of STX3451 in NF2deficient cells. These effects on the cytoskeleton undoubtedly contribute to the decrease in cell migration (Fig. 6) after treatment with the 2ME2 analogs, since disrupting microtubules can affect cellular locomotion [53]. Both STX3451 [31] and STX2895 [32] have been shown to inhibit tubulin assembly in vitro, presumably by binding to the colchicine-binding site of tubulin. Indeed, our recent X-ray crystalographic study [54] has demonstrated, in atomic detail, that a non-steroidal quinazolinone sulfamate derivative, similar to those investigated here, can interact with the colchicine binding site and microtubule destabilization is likely achieved by preventing the curved-to-straight conformational transition in $\alpha$ / $\beta$-tubulin. This is the first atomic level demonstration of such an interaction for a sulfamate ester. Associated crystallographic work has also demonstrated the effectiveness of STX3451 in binding to the colchicine site [55].

Our previous study showed that the non-steroidal analog of 2ME2, STX3451, caused microtubule depolymerization and cell death in NF1 deficient tumour cells, even in the presence of elevated hormones [30]. Whether steroid hormones affect the growth of $\mathrm{NF}^{-/-}$vestibular schwannomas (VS) and/or meningiomas has not been well-studied. It has been shown that in sporadic VS, both oestrogen receptor (ER) and progesterone receptor (PR) were up-regulated, whilst in NF2-related VS, PR was down-regulated [56]. Amongst meningioma patients, two-thirds express PR (although $-30 \%$ express PR at low levels), and during malignant progression, PR expression tends to decrease [57]. PRnegative meningiomas also tend to be larger than those that are PR-positive [58], and expression of PR in meningiomas is correlated with a favourable prognosis [59]. However, several studies have shown that hormone replacement therapy in postmenopausal women is associated with increasing the risk of meningiomas $[60,61]$ and one case report showed that cessation of long-term use of the PR agonist megestrol acetate resulted in shrinkage of multiple meningiomas in one patient [62]. Treatment of progressive meningiomas with the PR antagonist mifepristone has not shown promising results [63]. Therefore, hormone therapies are not indicated and may even be contraindicated for NF2-related tumours. The ability of STX3451 and STX2895 to inhibit colchicine binding to microtubules could play a major role in microtubule depolymerization and subsequent death of NF2 cells. However, the fact that, even at high concentration as $1 \mu \mathrm{M}, \mathrm{BJ}$ and IOMM-Lee cells still proliferate, although at a slower pace than the controls (Fig. 2), indicates that these small molecules could interact with players in the Merlin pathway in addition to their effects on microtubules. These possibilities need to be further investigated.

Since Merlin affects several key signalling pathways in the cytoplasm and nucleus, including PI3K signaling, mTORC1, the RAS and Src pathways, the Hippo kinase cascade, and CRL4-DCAF [64], inhibitors of these pathways might serve as excellent candidates for drug targets. Indeed, of the targeted drugs tested in clinics, bevacizumab, which is a VEGF antibody, showed some improvement in hearing and tumour shrinkage in a quarter to a half of patients with VS, albeit in very small numbers of study subjects [23-25]. Some phase II clinical trials with bevacizumab are still ongoing. The results of treatments with everolimus, an mTOR inhibitor, showed that it stabilized tumours or delayed tumour growth [26], but was ineffective for progressive VS [65]. Lapatinib, a tyrosine kinase inhibitor for the epithelial growth factor receptor (EGFR), showed some success in reducing VS volumes and improving hearing responses in about one-quarter of a small group of patients in a phase II study [22], but no effect on meningiomas. Other phase II studies of this drug are also ongoing.

So far, none of the drugs tested in vitro or in preclinical or clinical trials has been effective on NF2 meningioma. Although, another mTOR inhibitor, AZD-2014, and a combination of smoothened receptor inhibitor, 
vismodegib, and FAK inhibitor, vistusertib, are in phase II trials. AR-42, a histone deacetylase inhibitor targeting CRL4-DCAF, which induced meningioma cell apoptosis in vitro and in xenografts, is also in phase I trials. Even if some inhibitors for NF2/Merlin signalling pathways have promising efficacy, drug resistance to these inhibitors may eventually occur and alternative choices are necessary. The microtubule-disrupting non-steroidal 2ME2 analogs could provide another option for treating NF2related tumours, both vestibular Schwannomas and meningiomas, either alone, or in conjunction with other agents. Pre-clinical studies using several similar THIQbased molecules have been shown to be safe and efficacious for reducing the size of human breast cancer [66] and melanoma xenografts $[32,45]$ in immunocompromised mice. Before testing the usefulness of STX3451 and STX2895 in human schwannoma and meningioma patients, pre-clinical studies are warranted. It is our hope that someday these small molecules can advance to therapeutic use in such patients.

\section{Conclusion}

Both STX3451 and STX2895 provide new approaches for inducing cell death and lowering tumour burden in NF2 as well as in NF1, which both have limited treatment options.

\section{Abbreviations}

ER: oestrogen receptor; Merlin: Moesin-Ezrin-Radixin-like protein; MPNST: malignant peripheral nerve sheath tumours; NF1: Neurofibromatosis 1; NF2: Neurofibromatosis 2; PNF: plexiform neurofibroma; PR: progesterone receptor; THIQ: tetrahydroisoquinoline; VS: vestibular schwannomas

\section{Acknowledgements}

Support for this work was provided by the U.S. NSF: IOS1146132 and U.S. NIH: R25GM086262 to KFB; U.S. NIH: R01 CA148805 to JC, and the Wellcome Trust Senior Investigator grant to BVLP (grant 101010).

\section{Authors' contributions}

YS, CA, RM, BVLP and KFB were involved in the conception and design of the study, analyzing and interpreting data, writing the manuscript and revision of the final version. EMJ designed and performed statistical analyses. YS, CA and RM carried out experiments including cell culture and proliferation, IHC, migration, and invasion assays. WD and BVLP provided the synthetic compounds. WD, SK, JC, EMJ and BVLP contributed in writing the draft and revisions. All authors have read and approved the manuscript.

\section{Funding}

Support for this work was provided by the U.S. NSF: IOS1146132 and U.S. NIH: R25GM086262 to KFB; U.S. NIH: R01 CA148805 to JC and the Wellcome Trust to BVLP. BVLP is a Wellcome Trust Senior Investigator (grant 101010).

\section{Availability of data and materials}

All data generated or analyzed during this study are included in this published article. Extra information can be obtained from the corresponding author if needed.

Ethics approval and consent to participate

Not applicable.

\section{Consent for publication}

Not applicable.

\section{Competing interests}

The authors declare that they have no competing interests.

\section{Author details}

'Department of Cell and Developmental Biology, 3029 BSRB, University of Michigan Medical School, Ann Arbor, Michigan 48109-2200, USA.

${ }^{2}$ Department of Biomedical Engineering, College of Engineering, University of Michigan, Ann Arbor, Michigan 48109-2099, USA. ${ }^{3}$ Present Address: Department of Human Genetics, University of Michigan, Ann Arbor, Michigan 48109-5619, USA. ${ }^{4}$ NIH PREP program, Ann Arbor, Michigan 48109-5619, USA. ${ }^{5}$ Present Address: Biology Graduate Program, Stanford University, Stanford, CA 94305, USA. ${ }^{6}$ Cell and Molecular Biology Graduate Program, University of Michigan, Ann Arbor, Ml 48109, USA. 'Department of Electrical Engineering and Statistics, University of California, Berkeley, Berkeley, CA 94720-1770, USA. ${ }^{8}$ Medicinal Chemistry \& Drug Discovery, Department of Pharmacology, University of Oxford, Mansfield Road, Oxford OX1 3QT, UK. ${ }^{9}$ Cancer Biology Program, Fox Chase Cancer Center, 333 Cottman Ave, Philadelphia, PA 19111, USA.

Received: 16 May 2019 Accepted: 1 November 2019

Published online: 15 November 2019

\section{References}

1. Martuza RL, Eldridge R. Neurofibromatosis 2 (bilateral acoustic neurofibromatosis). N Engl J Med. 1988;318:684-8.

2. Carroll SL. Molecular mechanisms promoting the pathogenesis of Schwann cell neoplasms. Acta Neuropathol. 2012;123:321-48.

3. Gutmann DH, Ferner RE, Listernick RH, Korf BR, Wolters PL, Johnson KJ. Neurofibromatosis type 1. Nat Rev Dis Primers. 2017;3:17004.

4. Evans DG. Neurofibromatosis type 2. Handb Clin Neurol. 2015;132:87-96.

5. Evans DG. Neurofibromatosis 2 [bilateral acoustic neurofibromatosis, central neurofibromatosis, NF2, neurofibromatosis type II]. Genet Med. 2009;11:599-610.

6. McLaughlin ME, Kruger GM, Slocum KL, Crowley D, Michaud NA, Huang J, Magendantz M, Jacks T. The Nf2 tumor suppressor regulates cell-cell adhesion during tissue fusion. Proc Natl Acad Sci U S A. 2007;104:3261-6.

7. Lallemand D, Curto M, Saotome I, Giovannini M, McClatchey Al. NF2 deficiency promotes tumorigenesis and metastasis by destabilizing adherens junctions. Genes Dev. 2003;17:1090-100.

8. Pelton PD, Sherman LS, Rizvi TA, Marchionni MA, Wood P, Friedman RA, Ratner N. Ruffling membrane, stress fiber, cell spreading and proliferation abnormalities in human Schwannoma cells. Oncogene. 1998;17:2195-209.

9. Fraenzer JT, Pan H, Minimo L Jr, Smith GM, Knauer D, Hung G. Overexpression of the NF2 gene inhibits schwannoma cell proliferation through promoting PDGFR degradation. Int J Oncol. 2003;23:1493-500.

10. Hamaratoglu F, Willecke M, Kango-Singh M, Nolo R, Hyun E, Tao C, JafarNejad H, Halder G. The tumour-suppressor genes NF2/Merlin and Expanded act through hippo signalling to regulate cell proliferation and apoptosis. Nat Cell Biol. 2006;8:27-36.

11. Kalamarides M, Niwa-Kawakita M, Leblois H, Abramowski V, Perricaudet $M$, Janin A, Thomas G, Gutmann DH, Giovannini M. Nf2 gene inactivation in arachnoidal cells is rate-limiting for meningioma development in the mouse. Genes Dev. 2002;16:1060-5.

12. Giovannini M, Robanus-Maandag E, van der Valk M, Niwa-Kawakita M, Abramowski V, Goutebroze L, Woodruff JM, Berns A, Thomas G. Conditional biallelic Nf2 mutation in the mouse promotes manifestations of human neurofibromatosis type 2. Genes Dev. 2000;14:1617-30.

13. Chow HY, Stepanova D, Koch J, Chernoff J. p21-activated kinases are required for transformation in a cell-based model of neurofibromatosis type 2. PLoS One. 2010;5(11):e13791

14. Yi C, Troutman S, Fera D, Stemmer-Rachamimov A, Avila JL, Christian N, Persson NL, Shimono A, Speicher DW, Marmorstein R, et al. A tight junction-associated Merlin-angiomotin complex mediates Merlin's regulation of mitogenic signaling and tumor suppressive functions. Cancer Cell. 2011;19:527-40.

15. Zhou L, Hanemann CO. Merlin, a multi-suppressor from cell membrane to the nucleus. FEBS Lett. 2012;586:1403-8.

16. Petrilli AM, Fernández-Valle C. Role of Merlin/NF2 inactivation in tumor biology. Oncogene. 2016;35:537-48.

17. de Vries M, van der Mey AG, Hogendoorn PC. Tumor biology of vestibular Schwannoma: a review of experimental data on the determinants of tumor genesis and growth characteristics. Otol Neurotol. 2015;36:1128-36. 
18. Roger E. McLendon, Marc K. Rosenblum, Darell D. Bigner. Neurofibromatosis 2. Russell \& Rubinstein's Pathology of Tumors of the Nervous System $7^{\text {Ed }}$ 2006;p917-927.

19. Matthies C, Samii M. Management of 1000 vestibular schwannomas (acoustic neuromas): clinical presentation. Neurosurgery. 1997;40:1-9.

20. Baser ME, Evans DG, Jackler RK, Sujansky E, Rubenstein A. Neurofibromatosis 2, radiosurgery and malignant nervous system tumours. Br J Cancer. 2000; 82:998.

21. Balasubramaniam A, Shannon P, Hodaie M, Laperriere N, Michaels H, Guha A. Glioblastoma multiforme after stereotactic radiotherapy for acoustic neuroma: case report and review of the literature. Neuro-Oncology. 2007;9: 447-53.

22. Karajannis MA, Legault G, Hagiwara M, Ballas MS, Brown K, Nusbaum AO, Hochman T, Goldberg JD, Koch KM, Golfinos JG, et al. Phase II trial of lapatinib in adult and pediatric patients with neurofibromatosis type 2 and progressive vestibular schwannomas. Neuro-Oncology. 2012;14:1163-70.

23. Plotkin SR, Stemmer-Rachamimov AO, Barker FG II, Halpin C, Padera TP, Tyrrell A, Sorensen AG, Jain RK, di Tomaso E. Hearing improvement after bevacizumab in patients with neurofibromatosis type 2. N Engl J Med. 2009; 361:358-67.

24. Plotkin SR, Merker VL, Halpin C, Jennings D, McKenna MJ, Harris GJ, Barker FG 2nd. Bevacizumab for progressive vestibular schwannoma in neurofibromatosis type 2: a retrospective review of 31 patients. Otol Neurotol. 2012;33:1046-52.

25. Blakeley JO, Ye X, Duda DG, Halpin CF, Bergner AL, Muzikansky A, Merker VL, Gerstner ER, Fayad LM, Ahlawat S, et al. Efficacy and biomarker study of Bevacizumab for hearing loss resulting from Neurofibromatosis type 2associated vestibular Schwannomas. J Clin Oncol. 2016;34:1669-75.

26. Goutagny S, Raymond E, Esposito-Farese M, Trunet S, Mawrin C, Bernardeschi D, Larroque B, Sterkers O, Giovannini M, Kalamarides M. Phase II study of MTORC1 inhibition by everolimus in neurofibromatosis type 2 patients with growing vestibular schwannomas. J Neuro-Oncol. 2015;122: 313-20.

27. Ammoun S, Schmid MC, Triner J, Manley P, Hanemann CO. Nilotinib alone or in combination with selumetinib is a drug candidate for neurofibromatosis type 2. Neuro-Oncology. 2011;13:759-66.

28. Bush ML, Oblinger J, Brendel V, Santarelli G, Huang J, Akhmametyeva EM, Burns SS, Wheeler J, Davis J, Yates CW, et al. AR42, a novel histone deacetylase inhibitor, as a potential therapy for vestibular schwannomas and meningiomas. Neuro-Oncology. 2011;13:983-99.

29. Valencia H, Newton HB, Hade E, Sborov DW, Cavaliere R, Poi M, Phelps M, Wang J, Coss CC, Khountham S, et al. A phase 1 study of AR-42 in patients with advanced solid tumors, including nervous system tumors. J Clin Oncol 2016;34: suppl; abstr 2558.

30. Shen YC, Upadhyayula R, Cevallos S, Messick RJ, Hsia T, Leese MP, Jewett DM, Ferrer-Torres D, Roth TM, Dohle W, Potter BVL, Barald KF. Targeted NF1 cancer therapeutics with multiple modes of action: small molecule hormone-like agents resembling the natural anticancer metabolite, 2methoxyoestradiol. Br J Cancer. 2015;113:1158-67.

31. Dohle W, Leese MP, Jourdan FL, Chapman CJ, Hamel E, Ferrandis E, Potter BVL. Optimisation of tetrahydroisoquinoline-based chimeric microtubule disruptors. ChemMedChem. 2014;9:1783-93.

32. Leese MP, Jourdan FL, Major MR, Dohle W, Hamel E, Ferrandis E, Fiore A Kasprzyk PG, Potter BVL. Tetrahydroisoquinolinone-based steroidomimetic and chimeric microtubule disruptors. ChemMedChem. 2014;9:85-108.

33. Thomas MP, Potter BVL. Estrogen O-sulfamates and their analogues: clinical steroid sulfatase inhibitors with broad potential. J Steroid Biochem Mol Biol. 2015:153:160-9.

34. Thomas MP, Potter BVL. Discovery and development of the aryl O-Sulfamate moiety for oncology and women's health. J Med Chem. 2015;58:7634-58.

35. Potter BVL. SULFATION PATHWAYS: steroid sulphatase inhibition via aryl sulphamates: clinical progress, mechanism and future prospects. J Mol Endocrinol. 2018;61:T233-52.

36. Ireson CR, Chander SK, Purohit A, Parish DC, Woo LW, Potter BVL, Reed MJ. Pharmacokinetics and efficacy of 2-methoxyoestradiol and 2-methoxyoestradiolbis-sulphamate in vivo in rodents. Br J Cancer. 2004;90:932-7.

37. Andring JT, Dohle W, Tu C, Potter BVL, McKenna R. STX140 and nonsteroidal Sulfamate derivatives inhibit a carbonic anhydrase IX: structureactivity optimization for isoform selectivity. J Med Chem. 2019;62:2202-12.

38. Nel M, Joubert AM, Dohle W, Potter BVL, Theron AE. Modes of cell death induced by tetrahydroisoquinoline-based analogs in MDA-MB-231 breast and A549 lung cancer cell lines. Drug Design, Development and Therapy. 2018:12:1881-904.

39. Tanaka K, Sato C, Maeda Y, Koike M, Matsutani M, Yamada K, Miyaki M. Establishment of a human malignant meningioma cell line with amplified c-myc oncogene. Cancer. 1989;64:2243-9.

40. Püttmann $\mathrm{S}$, Senner $\mathrm{V}$, Braune $\mathrm{S}$, Hillmann B, Exeler R, Rickert $\mathrm{CH}$, Paulus W. Establishment of a benign meningioma cell line by hTERT-mediated immortalization. Lab Investig. 2005;85:1163-71.

41. Chow HY, Dong B, Duron SG, Campbell DA, Ong CC, Hoeflich KP, Chang LS, Welling DB, Yang ZJ, Chernoff J. Group I Paks as therapeutic targets in NF2deficient meningioma. Oncotarget. 2015;6:1981-94.

42. Tsai JC, Goldman CK, Gillespie GY. Vascular endothelial growth factor in human glioma cell lines: induced secretion by EGF, PDGF-BB, and bFGF. J Neurosurg. 1995;82:864-73.

43. Hung G, Li X, Faudoa R, Xeu Z, Kluwe L, Rhim JS, Slattery W, Lim D. Establishment and characterization of a schwannoma cell line from a patient with neurofibromatosis 2. Int J Oncol. 2002;20:475-82.

44. Lee WH. Characterization of a newly established malignant meningioma cell line of the human brain: IOMM-Lee. Neurosurgery. 1990;27:389-95.

45. Leese MP, Jourdan F, Kimberley MR, Cozier GE, Thiyagarajan N, Stengel C, Regis-Lydi S, Foster PA, Newman SP, Acharya K, et al. Chimeric microtubule disruptors. Chem Commun. 2010;46:2907-9.

46. Murray BW, Guo C, Piraino J, Westwick JK, Zhang C, Lamerdin J, et al. Smallmolecule p21-activated kinase inhibitor PF-3758309 is a potent inhibitor of oncogenic signaling and tumor growth. Proc Natl Acad Sci U S A. 2010;107: 9446-51.

47. Roth TM, Ramamurthy P, Ebisu F, Lisak RP, Bealmear BM, Barald KF. A mouse embryonic stem cell model of Schwann cell differentiation for studies of the role of neurofibromatosis type 1 in Schwann cell development and tumor formation. Glia. 2007:55:1123-33.

48. Roth TM, Ramamurthy P, Muir D, Wallace M, Zhu Y, Chang L, Barald KF. Influence of hormones and hormone metabolites on the growth of Schwann cells derived from embryonic stem cells and on tumor cell lines expressing variable levels of neurofibromin. Dev Dyn. 2008;237:513-24.

49. Iwasaki M, Homma S, Hishiya A, Dolezal SJ, Reed JC, Takayama S. BAG3 regulates motility and adhesion of epithelial cancer cells. Cancer Res. 2007; 67:10252-9

50. Chan KT, Asokan SB, King SJ, Bo T, Dubose ES, Liu W, Berginski ME, Simon JM, Davis IJ, Gomez SM, et al. LKB1 loss in melanoma disrupts directional migration toward extracellular matrix cues. J Cell Biol. 2014;207:299-315.

51. Crabbé A, Liu Y, Sarker SF, Bonenfant NR, Barrila J, Borg ZD, Lee JJ, Weiss DJ, Nickerson CA. Recellularization of decellularized lung scaffolds is enhanced by dynamic suspension culture. PLoS One. 2015;10(5):e0126846.

52. Fadeel B, Xue D. The ins and outs of phospholipid asymmetry in the plasma membrane: roles in health and disease. Crit Rev Biochem Mol Biol. 2009;44: 264-77.

53. Etienne-Manneville S. Microtubules in cell migration. Annu Rev Cell Dev Biol. 2013;29:471-99.

54. Dohle W, Jourdan FL, Menchon G, Prota AE, Foster PA, Mannion P, Hamel E, Thomas MP, Kasprzyk PG, Ferrandis E, et al. Quinazolinone-based anticancer agents: synthesis, Antiproliferative SAR, Antitubulin activity, and tubulin cocrystal structure. J Med Chem. 2018;61:1031-44.

55. Dohle W, Prota AE, Menchon G, Hamel E, Steinmetz MO, Potter BVL. Tetrahydroisoquinoline Sulfamates as potent microtubule disruptors: synthesis, anti-proliferative and anti-tubulin activity of Dichlorobenzyl derivatives and a tubulin co-crystal structure. ACS Omega. 2019;4:755-64.

56. Patel AK, Alexander TH, Andalibi A, Ryan AF, Doherty JK. Vestibular Schwannoma quantitative polymerase chain reaction expression of estrogen and progesterone receptors. Laryngoscope. 2008;118:1458-63.

57. Simon M, Boström JP, Hartmann C. Molecular genetics of meningiomas: from basic research to potential clinical applications. Neurosurgery. 2007;60: 787-98.

58. Brandis A, Mirzai S, Tatagiba M, Walter GF, Samii M, Ostertag H. Immunohistochemical detection of female sex hormone receptors in meningiomas: correlation with clinical and histological features. Neurosurgery. 1993;33:212-7.

59. Pravdenkova S, Al-Mefty O, Sawyer J, Husain M. Progesterone and estrogen receptors: opposing prognostic indicators in meningioma. J Neurosurg. 2006;105:163-73.

60. Jhawar BS, Fuchs CS, Colditz GA, Stampfer MJ. Sex steroid hormone exposures and risk for meningioma. J Neurosurg. 2003;99:848-53. 
61. Wigertz A, Lönn S, Mathiesen T, Ahlbom A, Hall P, Feychting M, Swedish Interphone Study Group. Risk of brain tumors associated with exposure to exogenous female sex hormones. Am J Epidemiol. 2006;164:629-36.

62. Vadivelu S, Sharer L, Schulder M. Regression of multiple intracranial meningiomas after cessation of long-term progesterone agonist therapy. J Neurosurg. 2010;112:920-4.

63. Grunberg SM, Weiss MH, Russell CA, Spitz IM, Ahmadi J, Sadun A, SitrukWare R. Long-term administration of mifepristone (RU486): clinical tolerance during extended treatment of meningioma. Cancer Investig. 2006;24:727-33.

64. Schroeder RD, Angelo LS, Kurzrock R. NF2/merlin in hereditary neurofibromatosis 2 versus cancer: biologic mechanisms and clinical associations. Oncotarget. 2014;5:67-77.

65. Karajannis MA, Legault G, Hagiwara M, Giancotti FG, Filatov A, Derman A, Hochman T, Goldberg JD, Vega E, Wisoff JH, et al. Phase II study of everolimus in children and adults with neurofibromatosis type 2 and progressive vestibular schwannomas. Neuro-Oncology. 2014;16:292-7.

66. Stengel C, Newman SP, Day JM, Chander SK, Jourdan FL, Leese MP, Ferrandis E, Regis-Lydi S, Potter BVL, Reed MJ, Purohit A, Foster PA. In vivo and in vitro properties of STX2484: a novel non-steroidal anti-cancer compound active in taxane-resistant breast cancer. Br J Cancer. 2014;111: 300-8.

\section{Publisher's Note}

Springer Nature remains neutral with regard to jurisdictional claims in published maps and institutional affiliations.

Ready to submit your research? Choose BMC and benefit from:

- fast, convenient online submission

- thorough peer review by experienced researchers in your field

- rapid publication on acceptance

- support for research data, including large and complex data types

- gold Open Access which fosters wider collaboration and increased citations

- maximum visibility for your research: over $100 \mathrm{M}$ website views per year

At BMC, research is always in progress.

Learn more biomedcentral.com/submissions 